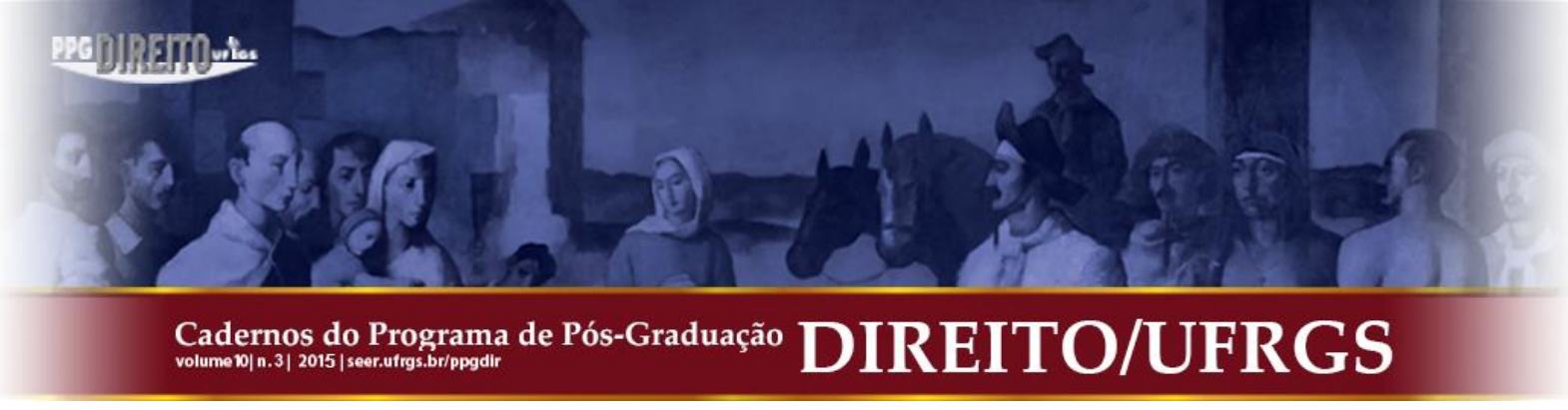

\title{
IMUNIDADES PARA INSTITUIÇÕES ASSISTENCIAIS E SEU IMPACTO NA SEGURIDADE SOCIAL: UMA VISÃO CONTEMPORÂNEA
}

\author{
IMMUNITIES TO ENTITIES OF SOCIAL ASSISTANCE AND ITS IMPACT ON SOCIAL \\ WELFARE: A CONTEMPORARY VIEW
}

Marcel Citro de Azevedo*

\begin{abstract}
RESUMO: Este trabalho apresenta uma visão contemporânea da discussão acerca do veículo legislativo apropriado para regulamentar as imunidades a contribuições previdenciárias previstas no artigo $195, \$ 7^{\circ}$ da Constituição Federal, medindo em especial o impacto desta indefinição sobre os serviços prestados por entidades assistenciais. Parte de um apanhado histórico sobre os primórdios da tributação até o advento do Estado Social de Direito, com o que define a espécie tributária contribuição e aponta suas particularidades. Discorre sobre o conteúdo normativo da expressão "entidades beneficentes de assistência social" e apresenta a discussão que se travou no Supremo Tribunal Federal, em 2014, tendente a definir se a regulamentação poderia ser realizada por lei ordinária ou se exige o diploma complementar.
\end{abstract}

PALAVRAS-CHAVE: Entidades beneficentes de assistência social. Imunidade tributária. Lei Complementar em matéria tributária. Requisitos materiais e formais para o gozo de imunidade tributária.
ABSTRACT: This paper presents a contemporary view regarding the discussion on the appropriate legislative vehicle to regulate immunities on social welfare contributions provided by the article 195, $\$ 7$ of the Brazilian Constitution, measuring in particular the impact of this uncertainty on the services provided by entities of social assistance. Starting from a historical overview on the beginnings of taxation until the advent of the Social Constitutional State, the paper comes to the definition of tax contribution species and points its peculiarities. The text also addresses the legal content of the expression "entities of social assistance" and presents a discussion that took place in the Brazilian Supreme Federal Court, in 2014, aiming to define whether the regulation could be made by ordinary law or if a supplementary law is required.

KEYWORDS Benevolent Entities of Social Assistance. Tax Immunity. Supplementary Law on Tax Matters. Substantial and procedural requirements in order to benefit from tax immunity.

SUMÁRIO: Introdução. 1 A Definição do Campo de Competência para o Custeio da Seguridade Social. 1.1 O financiamento direto por contribuições. 1.2 Normas de imunidade atinentes à seguridade. 2 A Regra Imunitória do Artigo 195, $\$ 7^{\circ} .2 .1$ Alcance e limites da expressão "entidades beneficentes de assistência social". 2.2 Lei ordinária ou lei complementar? Um ponto ainda a definir. Conclusão. Referências Bibliográficas.

\section{INTRODUÇÃO}

O presente artigo tem por objetivo analisar as normas imunitórias concernentes à tributação por contribuições, e mais especificamente, aquelas regras que retiram competência impositiva da União Federal no que tange ao custeio da seguridade social.

Sendo a seguridade o campo de atuação estatal que abrange a saúde, a assistência e a previdência social, seu estudo passa por um pequeno esboço histórico dos períodos antecedentes, em que o Direito não priorizava o ser humano em sua integralidade. O estudo do

\footnotetext{
* Mestrando em Direito pela Universidade Federal do Rio Grande do Sul (UFRGS). Juiz Federal vinculado à $4^{a}$ Região, professor de Direito Tributário da Escola da Magistratura Federal e diretor cultural da Associação dos Juízes Federais do Rio Grande do Sul.
} 


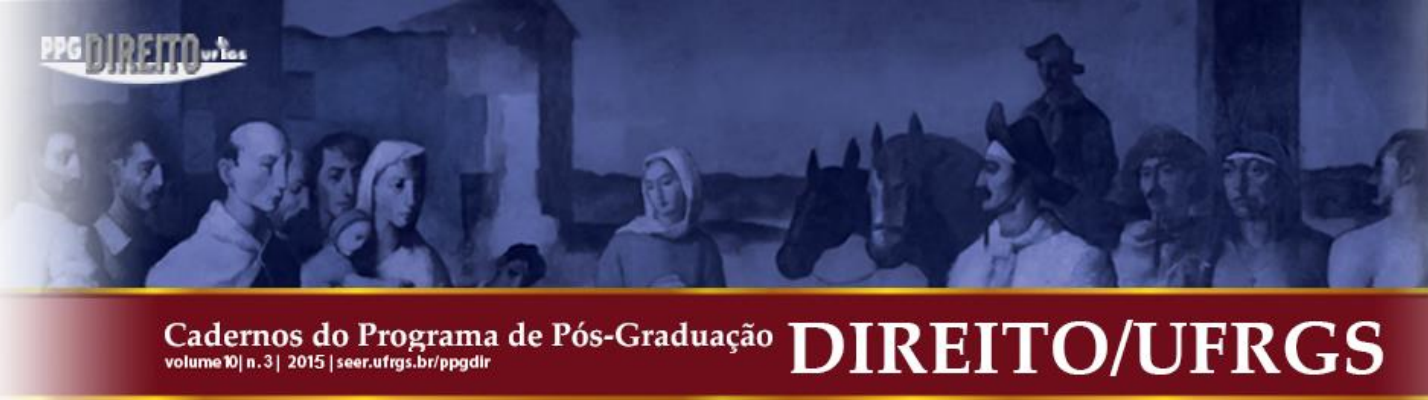

Estado Fiscal Contemporâneo, pressuposto e condicionante do Estado Social de Direito, é melhor realizado mediante a comparação das práticas atuais e as de outrora.

Isso porque no estágio atual de desenvolvimento do direito pátrio, o cidadão, mais do que simples administrado, passou a ser proativo e cônscio de sua posição perante o Estado. Não há mais mera relação de poder entre o contribuinte e os entes tributantes, com a justificação de condutas marcadas pelo autoritarismo e pelo arbítrio no jus imperium, mas sim relação jurídica pontilhada de direitos e deveres de parte a parte.

Pode-se afirmar, por conseguinte, que também as relações com o fisco vêm se desenvolvendo sob o pálio do primado dos direitos fundamentais, adquirindo especial significado o papel do princípio da dignidade humana (art. $1^{\circ}$, III, da CF). Tal princípio possui eficácia irradiante na definição e alcance do mínimo existencial, entendido como detentor de uma dupla conotação: proteção negativa contra a tributação excessiva e proteção positiva ao constituir-se o ser humano como destinatário de conjunto mínimo de prestações materiais no que tange à seguridade e à educação fundamental.

Neste particular, Ricardo Lobo Torres ressalta que o conceito de mínimo existencial está ligado ao conceito de liberdade, visto que não há alternativas de escolha em condições mínimas de sobrevivência (TORRES, 2000, p. 90-92). A preponderância do valor da dignidade da pessoa humana e da manutenção do mínimo existencial funda-se sobre a ideia da solidariedade social. ${ }^{1}$

O paradoxal é que o tributo, historicamente, sempre esteve associado à perda da liberdade. $\mathrm{Na}$ antiguidade, povos vencidos deveriam pagar tributos aos vencedores, como contrapartida de não terem sido arrasadas as suas aldeias e plantações, ou mesmo não terem sido serem tomados como escravos pelos agressores. Daí vem o termo tributo, cuja etimologia remete a repartir por tribos, ou seja, dividir os despojos e resultados da guerra por entre as tribos que, conduzidas por um líder guerreiro, lograram obter o êxito militar (COSTA, 2015, p. 33).

Durante a formação do Estado Nacional, a situação se manteve, com a renda dos tributos direcionadas o mais das vezes para o benefício exclusivo de determinados estamentos - o rei, a nobreza, o alto clero - em detrimento do interesse coletivo. Essa situação só veio a modificarse a partir do século XVIII, com o influxo das idéias iluministas.

\footnotetext{
1 Nos termos do art. $3^{\circ}$ da Constituição, é objetivo da república brasileira a construção de uma sociedade que seja livre, justa e solidária.
} 


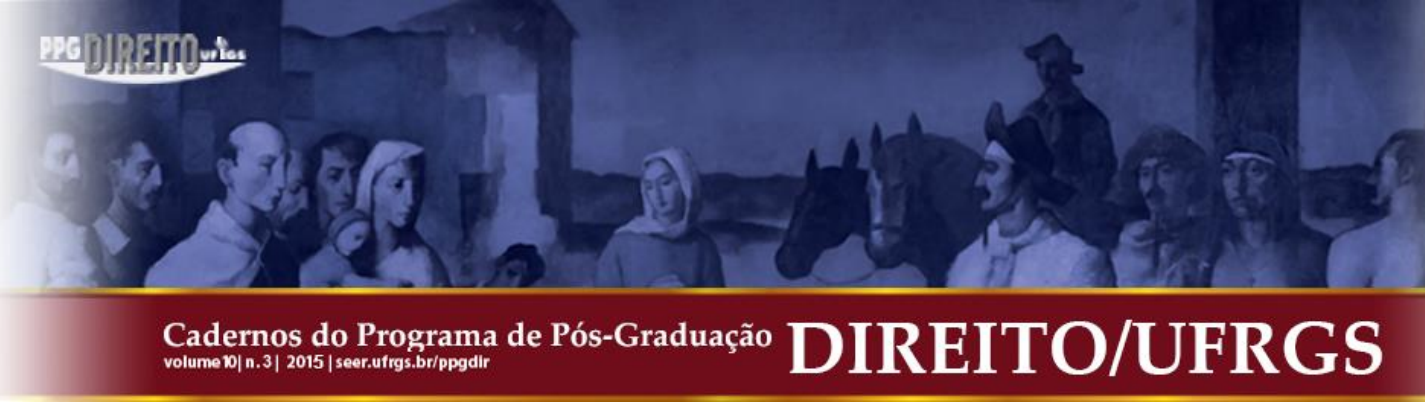

Tais quais os impostos, as contribuições especiais incidem sobre fatos ou situações correlacionados aos contribuintes, não ao Poder Público, mas são destinadas, pela própria legislação tributária, à concretização de finalidades estatais específicas. Exemplificativamente, a União pode cobrar a contribuição ao salário-educação com base na competência consagrada no art. $212, \S 5^{\circ}$, da $\mathrm{CF}$, mas para tanto deve ater-se à sua finalidade própria, que é custear o ensino fundamental público. O titular da capacidade tributária ativa não pode exigi-la para financiar, por exemplo, a educação superior.

É exatamente este aspecto teleológico que diferencia as normas concessivas de competência para a instituição de contribuições especiais das que autorizam a cobrança de impostos. Marco Aurélio Greco, na sua obra clássica Contribuições: uma figura sui generis (2000, p. 119), refere com precisão que o critério de validação constitucional da contribuição é a sua finalidade. A Constituição da República autoriza a edição de uma lei não porque tenha acontecido algo ou porque se esteja diante de determinada situação, mas para que se obtenha um dado resultado. Refere tratar-se de um "modelo fundamentalmente para que se atinja algo, implicando visão muito mais modificadora da realidade" (GRECO, 2000, p. 119).

Neste contexto, cabe referir que jamais poderá ser confundida a finalidade com o fato gerador das obrigações tributárias ${ }^{4}$, pois tais fatos geradores correspondem às manifestações de riqueza dos contribuintes que deixam entrever a capacidade contributiva e, por isso, eleitos para ensejarem as obrigações de prestar dinheiro para destinações constitucionalmente relevantes.

Há também que ser destacada uma terceira nota distintiva das contribuições em relação às demais espécies: a sua referibilidade, entendida como pertinência ou referência a certo conjunto de contribuintes, o qual será chamado a suportar o gravame adicional que elas representam. Mais precisamente, é o liame entre a finalidade da contribuição e o grupo dos sujeitos passivos instados a suportar o seu ônus.

A referibilidade constitui-se, assim, na relação de pertinência que deve existir entre a atividade a ser custeada e aquelas pessoas físicas e jurídicas chamadas a contribuir. Não se exige que o contribuinte seja beneficiado pela atividade, ou que dela obtenha alguma vantagem, basta que integre um grupo a que se refere, de alguma maneira, à atividade custeada. Impõe-se, pois, uma motivação racional que justifique a tributação.

\footnotetext{
${ }^{4}$ Nos termos do artigo 113 do CTN, são as situações previstas em lei como necessárias e suficientes ao surgimento das referidas obrigações fiscais.
} 


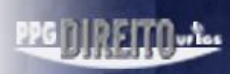 \\ Cadernos do Programa de Pós-Graduação
volume $10 \mid$ n.3| 2015 | seer.ufrgs.br/ppgdir}

ordinária, pois o art. 146, III, "a" da Constituição, ao prever lei complementar que contemple normas gerais, faz referência apenas à espécie tributária imposto no que tange a fatos geradores, bases de cálculo e contribuintes. Uma leitura a contrario sensu do artigo conduz à ilação de que tais fatos geradores, bases de cálculo e contribuintes das Contribuições Sociais de Seguridade Social podem ser definidas pela espécie legislativa ordinária, que requer tão só simples maioria parlamentar para a sua aprovação.

Dada à natureza indiscutivelmente tributária das contribuições, não há dúvidas de que o conteúdo do caput do artigo 195 está deslocado. Deveria integrar o título VI da Carta, concernente à Ordem Econômica e Financeira, ao invés do titulo atinente à Ordem Social. Todavia, esta impropriedade do poder constituinte originário é contornada pela existência do artigo 149, ínsito à tributação e que se correlaciona com o referido artigo 195 como um detalhamento da subespécie contribuição social de seguridade social.

Por outro lado, compete exclusivamente à União instituir tais contribuiçõos, o que se harmoniza com a competência privativa do artigo 22, XXIII. Já no que concerne ao regime previdenciário dos servidores estaduais, distritais e municipais, o artigo $149, \S 1^{\circ}$ encontra consonância no art. 24, I, que trata da competência concorrente para legislar sobre direito tributário, e art. 24, XII, relativo à competência concorrente para editar normas sobre previdência social.

O texto constitucional, em sua acepção original, estabelecia por meio do art. 195 que a seguridade social seria financiada por "toda a sociedade, de forma direta e indireta", por meio de recursos provenientes dos orçamentos dos entes políticos e de contribuições sociais cobradas "do empregador, incidentes sobre a folha de salários, faturamento e lucro". Esta redação original ensejou um sem número de ações versando sobre o avanço da legislação de regência sobre os limites da autorização constitucional, procurando tributar situações que se situavam à margem da norma de competência.

Decidindo as questões a ele submetidas, o STF entendeu que a competência concedida alcançava até mesmo os potenciais empregadores (RE 364.215, Relator Ministro Carlos Velloso), mas que não se poderia incluir no conceito de Folha de Salário a remuneração paga aos administradores, avulsos e autônomos (ADI 1.102, Relator Ministro Mauricio Côrrea), nem alargar o conceito de faturamento para incluir também receitas financeiras (RE 346.084, Relator Ministro Marco Aurélio).

Cadernos do Programa de Pós-Graduação em Direito PPGDir./UFRgS | Edição Digital | Porto Alegre | Volume X | Número 3 | 2015 | P. 166-190 


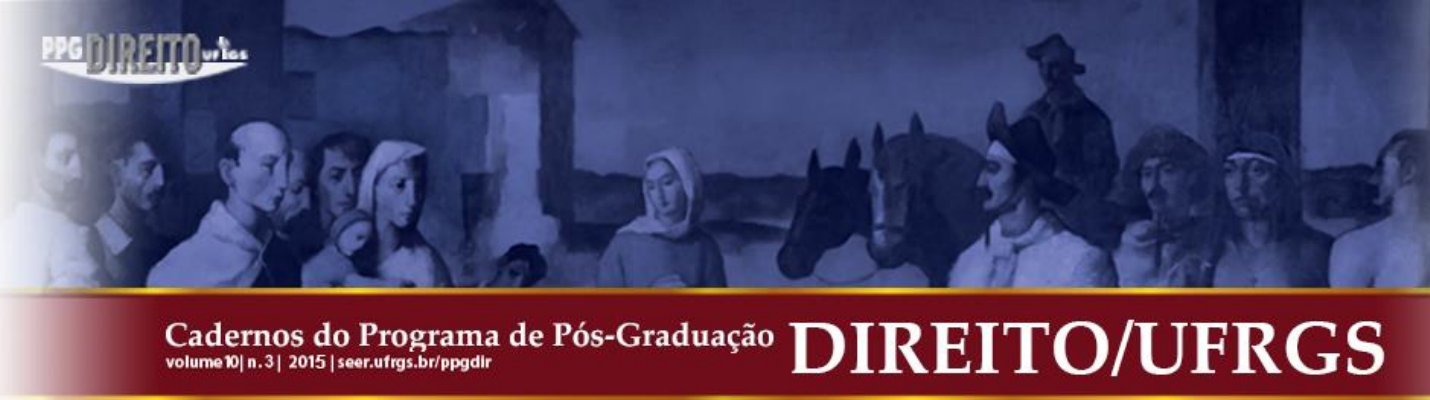

vendas para o exterior, visando justamente à promoção das exportações e, por conseguinte, o desenvolvimento nacional e a erradicação da pobreza, nos termos do artigo $3^{\circ}$, II e III da CF. Trata-se de imunidade objetiva, concedida à prestação de serviços no estrangeiro ou a operações que transfiram produtos para o exterior, e não imunidade subjetiva às empresas exportadoras, de forma que não alcança o lucro (STF, pleno, RE 564.413, Rel. Min. Marco Aurélio). Também não alcança as movimentações financeiras decorrentes das operações de exportação, tributadas à época pela CPMF e, em alguns casos, pelo IOF, já que tais aplicações bancárias são posteriores à operação de exportação em si.

Como assevera Andrei Pitten Velloso (2007, p. 186), tal imunidade

\begin{abstract}
Almeja desenvolver a indústria interna e o comércio internacional, levando á criação de postos de trabalho e ao desenvolvimento da economia como um todo, fatos que por sua vez implicam um incremento na base contributiva, fazendo com que as perdas de arrecadação decorrentes da imunidade sejam parcial ou totalmente compensadas.
\end{abstract}

Chegamos, assim, à norma do artigo $195 \S 7^{\circ}$, que trata de verdadeira imunidade, e não de isenção. O equívoco da redação já foi solucionado pelo Supremo na Medida Cautelar na Ação Direta de Inconstitucionalidade $n^{\circ}$ 2.028/DF, relator ministro Moreira Alves. É imunidade por constituir-se limitação ao poder de tributar com sede constitucional, que suprime competência impositiva.

Ao relatar o RE 636941, em fevereiro de 2014, o Ministro Luiz Fux salientou que

\begin{abstract}
A expressão 'isenção' equivocadamente utilizada pelo legislador constituinte decorre de circunstância histórica, porquanto versa o tema de verdadeira imunidade. O primeiro diploma legislativo a tratar da matéria foi a Lei $\mathrm{n}^{\circ} 3.577 / 59$, que isentou a taxa de contribuição de previdência dos Institutos e Caixas de Aposentadoria e Pensões às entidades de fins filantrópicos reconhecidas de utilidade pública, cujos membros de sua diretoria não percebessem remuneração.
\end{abstract}

Como a imunidade às contribuições sociais somente foi introduzida na Carta Constitucional de 1988, esclareceu o relator que "a transposição acrítica do seu conteúdo, com o viés do legislador ordinário de isenção, gerou esta controvérsia, já superada pela jurisprudência desta Suprema Corte no sentido de se tratar de imunidade” (STF, RE 636941).

\title{
2 A REGRA IMUNITÓRIA DO ARTIGO $195 \$ 7^{\circ}$ DA CONSTITUIÇÃO
}

\subsection{Alcance e limites da expressão "entidades beneficentes de assistência social"}




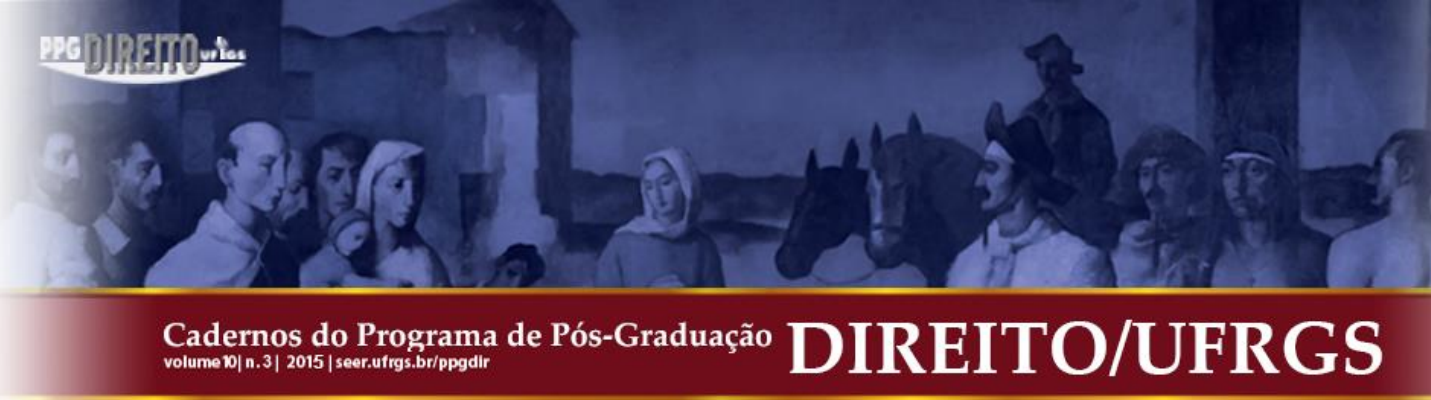

Não obstante a regra imunitória em tela tratar-se de uma limitação constitucional ao poder de tributar, não foi editada a lei complementar sobre a matéria. De fato, com exceção da LC 104/01, que alterou pontualmente o artigo 14, I do CTN, a matéria carece de legislação complementar, em que pese tenham sido editadas várias leis ordinárias versando sobre o assunto.

O Supremo Tribunal Federal vinha entendendo que o CTN, em seu artigo 14, faz às vezes da regulamentação faltante, já que a Lei 5.172/66 foi recepcionada com status de lei complementar pelo regime constitucional vigente.

Assim dispõe o CTN:

Art. 14. O disposto na alínea "c" do inciso IV do art. $9^{\circ}$ é subordinado à observância
dos seguintes requisitos pelas entidades nele referidas:
I - não distribuírem qualquer parcela de seu patrimônio ou de suas rendas, a qualquer
título; (Nova redação conforme a LC $104 / 2001$, vigente desde a publicação em
11/01/01)
II - aplicarem integralmente, no País, os seus recursos na manutenção dos seus
objetivos institucionais;
III - manterem escrituração de suas receitas e despesas em livros revestidos de
formalidades capazes de assegurar sua exatidão.

Sobre a aplicação do artigo retro transcrito também sobre as contribuições sociais de seguridade, Leandro Paulsen esclarece (2011, p. 579):

$\mathrm{O}$ art. 14 do CTN regula a imunidade relativa a impostos incidentes sobre o patrimônio, renda ou serviços dos partidos políticos, sindicatos, instituições de educação e de assistência social, sem fins lucrativos. Entretanto, na ausência de regulação, por lei complementar, da imunidade relativa às contribuições de seguridade social das entidades beneficentes de assistência social prevista no art. $195, \S 7^{\circ}$, da $\mathrm{CF}$, a doutrina e mesmo os tribunais têm entendido que assume também este papel.

No que tange ao inciso I do artigo em referência, cabe assinalar que o pagamento de salários a dirigentes não afeta a imunidade das entidades beneficentes sem fins lucrativos, desde que não haja uma distribuição de resultado disfarçada, com o pagamento muito acima dos padrões de mercado.

No que se refere ao inciso II, trata-se da exigência que a entidade que almeja o favor constitucional não remeta parcela do seu resultado positivo para o exterior, o que era bastante comum na assistência social, com entidades de inspiração religiosa que desenvolviam serviços na área de saúde ou educação instadas a tais remessas para a instituição mantenedora geralmente patrocinada por alguma ordem situada na Europa (maristas e jesuítas de tradição católica, luteranos e adventistas de inspiração protestante, entre outros credos). Em que pese a 


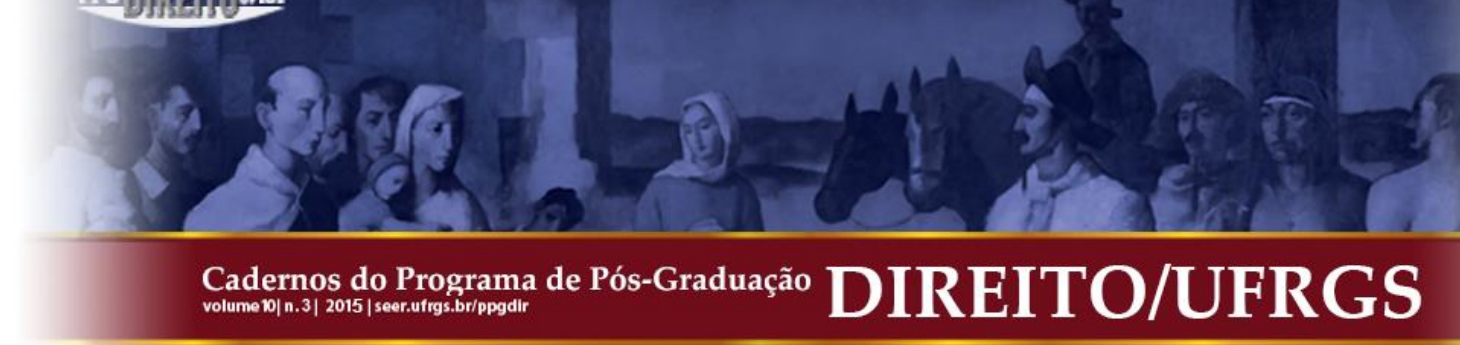

possibilidade do reenvio de recursos para outras áreas sensíveis do globo, quiçá ainda mais necessitadas do que o Brasil, a norma complementar exige, com razão, que eventual resultado positivo seja reaplicado integralmente no país. Concede-se a imunidade, portanto, sob a condição do reinvestimento para manter ou ampliar o atendimento aos hipossuficientes brasileiros.

O inciso III, por fim, veicula norma que é, em verdade, uma garantia da observância das duas antecedentes. Só por intermédio de uma contabilidade idônea, bem escriturada e em conformidade com as leis contábeis é que se pode assegurar que não se está frente a uma distribuição disfarçada de resultado a gestores, ou a uma remessa irregular de recursos ao estrangeiro.

O artigo 55 da lei 8212/91, ora revogado, e a lei 12.101/09 pretenderam acrescentar outros requisitos e condicionantes àqueles expressos acima. A questão é saber se lei ordinária pode estabelecer requisitos formais, caso em que se interpretará a menção à lei no artigo $195 \S 7^{\circ}$ como mera referência ao princípio da reserva legal, ou se apenas o diploma complementar possa dispor validamente sobre o tema, caso em que se teria evitado no texto constitucional o qualificativo complementar tão só para evitar a tautologia. Esta ambiguidade da norma, dada à relevância e a atualidade do tema - o assunto está sendo debatido ao longo deste ano de 2014 será tratada em tópico específico.

De qualquer maneira, é certo que não se pode definir o alcance de uma expressão sem analisar primeiramente a finalidade que inspira a formulação de seu conteúdo. A finalidade da exoneração constitucional é justamente induzir os cidadãos e as pessoas jurídicas em geral a auxiliarem o estado nas importantes atividades concernentes à seguridade social, prática que deve ser incentivada já que é bastante comum haver insuficiência de cobertura e atendimento à população, escassez de benefícios e serviços ofertados, bem como equívocos na implementação de políticas públicas de saúde e assistência, quando não desperdício e ineficiência explícitos.

De fato, a lógica na concessão desta desoneração de sede constitucional é de fácil entendimento. Como o Estado Brasileiro se erige sobre o princípio da dignidade da pessoa humana, não haveria sentido em onerar com tributos aqueles entes que realizam precipuamente a atividade que os governos dos entes federados deveriam realizar, diminuindo assim, com a tributação, os recursos destinados para a finalidade.

Ademais, não possuem os órgãos estatais condições materiais de efetivar os amplos objetivos correlacionados à prestação de serviços de saúde, previdência e assistência sem a 


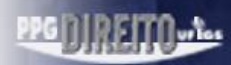 \\ Cadernos do Programa de Pós-Graduação
volume $10 \mid$ n.3| 2015 |seer.ufrgs.br/ppgdir}

imprescindível ajuda da sociedade civil, tanto que o próprio caput do artigo 194 prevê a sua participação de forma expressa. Ora, se pessoas jurídicas de direito privado sem fins lucrativos estão suprindo deficiências do próprio estado, incapaz de formular e executar políticas públicas abrangentes que possam garantir o mínimo existencial no que tange à seguridade, nada mais razoável do que imunizá-las do pagamento de tributos instituídas com a finalidade de, exatamente, financiar as políticas públicas que o estado não dá conta de executar com o alcance e a eficiência necessários.

Vale reprisar a lição de Marco Aurélio Greco (2000, p. 120), a espécie tributária contribuição nada mais é do que um instrumento para a atuação estatal em áreas constitucionalmente relevantes. Se o Estado brasileiro é dispensado de atuar porque o particular já está agindo neste desiderato, então o instrumento tributação é prescindível no que concerne àquele que realiza a prestação diretamente.

Por outro lado, o termo assistência social está vinculado à ideia de auxiliar o pleno desenvolvimento da pessoa humana. O Estado social moderno, razão principal da existência do Estado fiscal a ele subjacente, tem o dever de oferecer condições mínimas de vida ao cidadão, propiciando-lhe uma existência com dignidade. Assim, a assistência social destina-se a proteger primeiramente a família, ainda a célula mater da sociedade e primeiro invólucro do indivíduo. Após, a pessoa da gestante carente, por ações coordenadas na área assistencial e de saúde. Infância e adolescência, períodos que demandam especial cuidado em função das questões relativas ao abandono e à drogadição, devem receber redobrada atenção nas situações em que estas problemáticas são potencializadas pela pobreza. Por fim, também a velhice demanda serviços assistenciais crescentes por parte do estado, mormente considerando que o aumento da expectativa de vida sem ganhos proporcionais em sua qualidade resultam muitas vezes em idosos carentes de forças para prover o próprio sustento.

Vê-se, assim, que a assistência social não se subsume ao artigo 203 da Carta Política. Nas três áreas da seguridade social há uma interpenetração mútua de programas e atividades concernentes às outras duas, uma vez que o que se protege é o ser humano na sua integralidade. Não há de se falar, pois, em uma interpretação estanque ou separatista da seguridade social. O equívoco desta exegese se evidencia face ao amplo universo de riscos sociais que podem acometer o cidadão, pertencentes às mais diversas ordens. Assim, por exemplo, tutela-se a senelitude de um cidadão humilde que postula a aposentadoria rural com programas previdenciários e ações do SUS, pois de nada adianta garantir-lhe um salário assistencial de um 


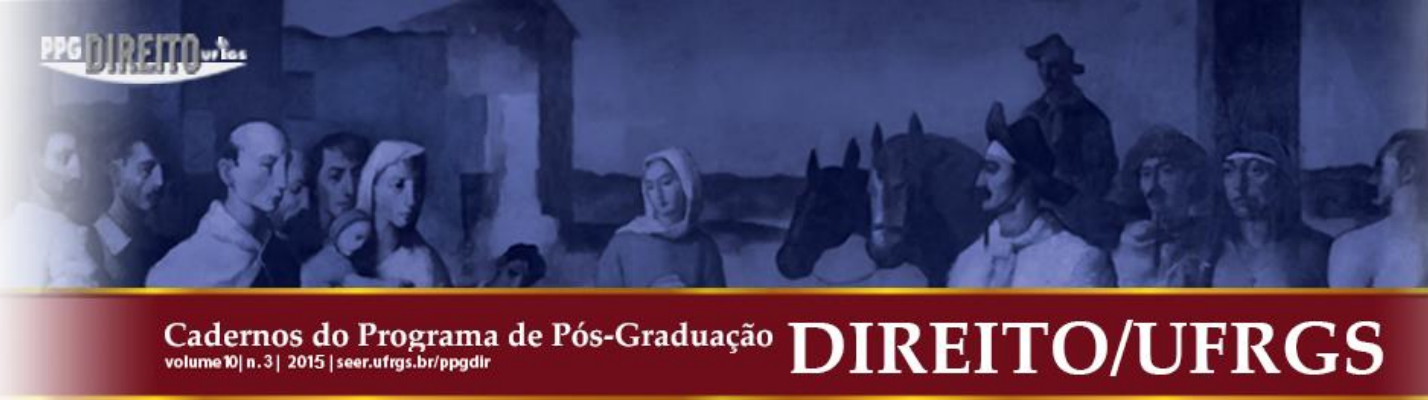

mínimo (CF, art. 203, V) se não lhe for garantido um tratamento a uma doença crônica que lhe ameaça a vida e lhe causa dor física intensa. Salvaguarda-se o adolescente do risco das ruas com programas assistenciais ligados à prática do esporte, mas também com ações de ensino e saúde, e assim sucessivamente.

Nos termos do voto proferido pelo Min. Marco Aurélio no RE 566.622- RS, o STF

\begin{abstract}
Reconhece sentido mais amplo ao termo "assistência social" constante do artigo 203 da Carta de 1988, concluindo que, entre as formas de promover os objetivos revelados nos incisos desse preceito, estão incluídos os serviços de saúde e educação. Toda pessoa jurídica que preste esses serviços, sem fins lucrativos, com caráter assistencial, em favor da coletividade e, em especial, dos hipossuficientes, estará atuando em concerto com o Poder Público na satisfação de direitos fundamentais sociais.
\end{abstract}

Tem-se, assim, que as entidades de assistência social devem atuar conjuntamente com o Poder Público para concretizar os objetivos almejados pelo multimencionado artigo 203. Para tanto, necessitam de desoneração em sede constitucional, que prive o ente tributante de qualquer tentação de valer-se de maiorias ocasionais no parlamento para aumentar a arrecadação, reduzindo ou ampliando o alcance de eventual isenção que viesse a conceder consoante às circunstancias econômicas e políticas do momento.

Com efeito, não há sentido algum em se onerar com a instituição de contribuição social recursos do ente que está prestando diretamente o benefício ou serviço à população destinatária da atuação estatal. O mínimo exigível, neste caso, é que o Estado não tribute manifestações de capacidade econômica tendentes a serem revertidas na manutenção ou ampliação de atividade assistencial pelos particulares.

Ademais, as contribuições são destinadas a prover de recursos a seguridade social como um todo, o que também compreende a área previdenciária, cujo regime é contributivo e não distributivo. Seria um contrassenso retirarem-se recursos de quem presta atividades assistenciais para aplicá-lo em área não assistencial.

Nesta mesma linha de raciocínio, não se pode limitar o status de entidade de assistência social tão só aquelas organizações que prestam assistência em uma concepção estrita, nos moldes das antigas Santas Casas de Misericórdia. Tal interpretação assaz restritiva não se coaduna com a noção de um estado plural, social e democrático de direito. Desta forma, o alcance da expressão entidade beneficente se sobrepõe ao espectro mais limitado das sociedades filantrópicas, que se mantém tão só por doações.

\footnotetext{
${ }^{8}$ Processo em julgamento.

Cadernos do Programa de Pós-Graduação em Direito PPGDir./UFRgS | Edição Digital | Porto Alegre | Volume X | Número 3 | 2015 | P. 166 -190
} 


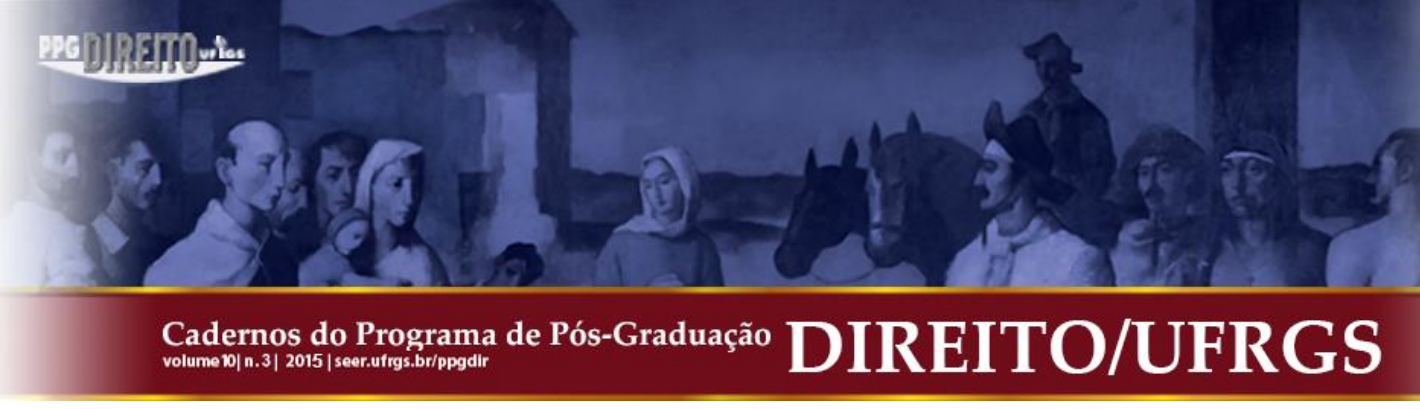

não havia sido alegada a inconstitucionalidade do referido artigo 55, o ministro Marco Aurélio ao proferir seu voto asseverou estar relatando um recurso extraordinário mais abrangente (RE 566622), que abarcava inclusive a lei 8212/91.

Quatro meses depois, ao ser colocado em pauta o referido recurso extraordinário, o ministro Marco Aurélio (RE 566622) asseverou:

A parte final do $\S 7^{\circ}$ do artigo 195 autoriza o legislador a impor condições ao gozo, pelas entidades beneficentes de assistência social, do direito à imunidade. A questão controversa refere-se à espécie legislativa credenciada pela Carta para estabelecer as condições necessárias. Na solução do litígio, deve o Supremo seguir a linha hermenêutica utilizada quanto às outras espécies de imunidade e compreender a cláusula de reserva legal tendo em conta a unidade da Constituição e as funções políticas e sociais próprias da imunidade ora discutida. O Tribunal deve manter a interpretação sistemática e teleológica. (...) Daí que, em se tratando de autêntica limitação ao poder de tributar, "exigências legais" ao exercício das imunidades são sempre "normas de regulação" às quais fez referência o constituinte originário no inciso II do artigo 146, no qual consta devam ser as mesmas dispostas em lei complementar.

E aduziu que "sob o pretexto de disciplinar aspectos das entidades pretendentes à imunidade", o legislador ordinário acabou por restringir de forma indevida o alcance subjetivo da regra constitucional, "impondo condições formais reveladoras de autênticos limites à imunidade" e promovendo a regulação do direito ao arrepio do veículo legislativo previsto no 146, inciso II, da Carta Política. Transcreveu em seu voto lição de Ives Gandra Martins (1994, p. 83) para esclarecer que a lei ordinária não pode veicular condicionantes além dos previstos no CTN, nos seguintes termos:

\footnotetext{
Nenhuma lei ordinária de qualquer poder tributante pode criar requisitos adicionais, impondo ônus que o constituinte deliberadamente quis afastar. Todos os requisitos acrescentados ao restrito elenco do artigo 14 são inconstitucionais, em face de não possuir o Poder Tributante, nas três esferas, nenhuma força legislativa suplementar. Apenas a lei complementar pode impor condições. Nunca a lei ordinária, que, no máximo, pode reproduzir os comandos superiores.
}

Sumarizando, pode-se dizer que em sua última manifestação sobre o tema o STF inclinase para entender que o artigo 55 da Lei $\mathrm{n}^{\circ}$ 8.212, de 1991 define requisitos para o exercício da imunidade tributária que se consubstanciam em "verdadeiras condições prévias ao aludido direito", razão pela qual "deve ser reconhecida a inconstitucionalidade formal desse dispositivo no que extrapola o definido no artigo 14 do Código Tributário Nacional, por violação ao artigo 146, inciso II, da Constituição Federal" (Min. Marco Aurélio, RE 566622). E tende a estabelecer que os requisitos legais cabíveis são somente aqueles do referido artigo 14 do CTN. 


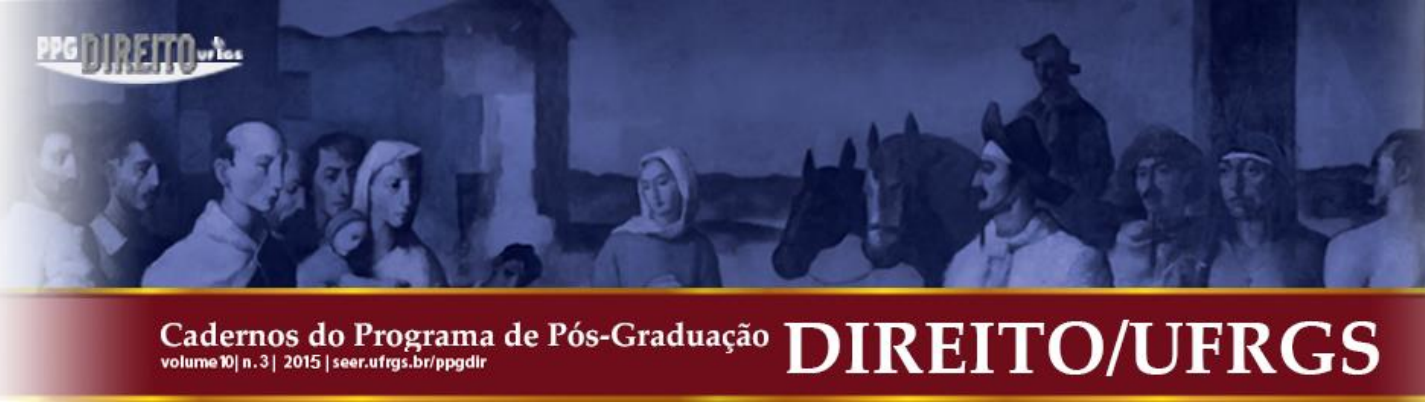

Imaginamos que seja esta a tendência de nosso tribunal constitucional porque quatro votos foram proferidos a favor dos contribuintes, já que os ministros Joaquim Barbosa, Cármen Lúcia e Luís Roberto Barroso acompanharam o relator, tendo sido o julgamento interrompido pelo pedido de vista do ministro Teori Zavascki.

Neste particular, pensamos que o posicionamento adotado pelo relator e seguido pelos três ministros referidos é o mais correto. A uma, porque o art. 146, II da Carta Política não diferencia requisitos objetivos e subjetivos, sendo assente a regra interpretativa pela qual nos pontos em que a Constituição não diferencia não cabe ao intérprete diferenciar. A duas, porque o particular que colabora com o Estado na prestação de serviços de ensino e seguridade aos hipossuficientes tem direito constitucionalmente assegurado à regulação integral do tema por espécie legislativa que exige maior consenso parlamentar, constituindo um atentado a sua segurança jurídica a permissão de que o benefício constitucional seja restringido por mera lei ordinária, o que o mais das vezes é resultado da conversão de medida provisória. A três, porque este direito não pode ser mutilado por intermédio de uma dissociação não embasada em uma análise sistemática da $\mathrm{CF}$.

Este último argumento desafia um esclarecimento adicional: pensamos que não há amparo sistemático para exigir-se que a referência à lei complementar seja expressa a cada vez que veiculada limitação ao poder de tributar, pois tal resultaria em exigir-se do poder constituinte, que em suas subespécies poder originário e poder complementar jamais adotou uma linguagem técnica, a reiteração da prática do vício de linguagem da tautologia, como se os destinatário dos comandos constitucionais não fossem capazes de compreender os desideratos últimos da Constituição.

Assim, consoante o artigo 146, II da CF, limitações constitucionais ao poder de tributar só devem ser tratadas por meio de lei complementar. Não só pelos argumentos já alinhavados, mas porque a imunidade é um limite, seja pela sua localização tópica no texto da carta política, seja porque implica efetivamente em um freio ao poder de exigir prestações pecuniárias compulsórias de quem demonstre alguma capacidade contributiva.

Haveria ainda um argumento adicional: a lei ordinária não teria o condão de instituir limites efetivos ao legislador tributário também porque na espécie tributária contribuições o fato gerador, a base de cálculo e os contribuintes podem ser estabelecidos justamente por tal 


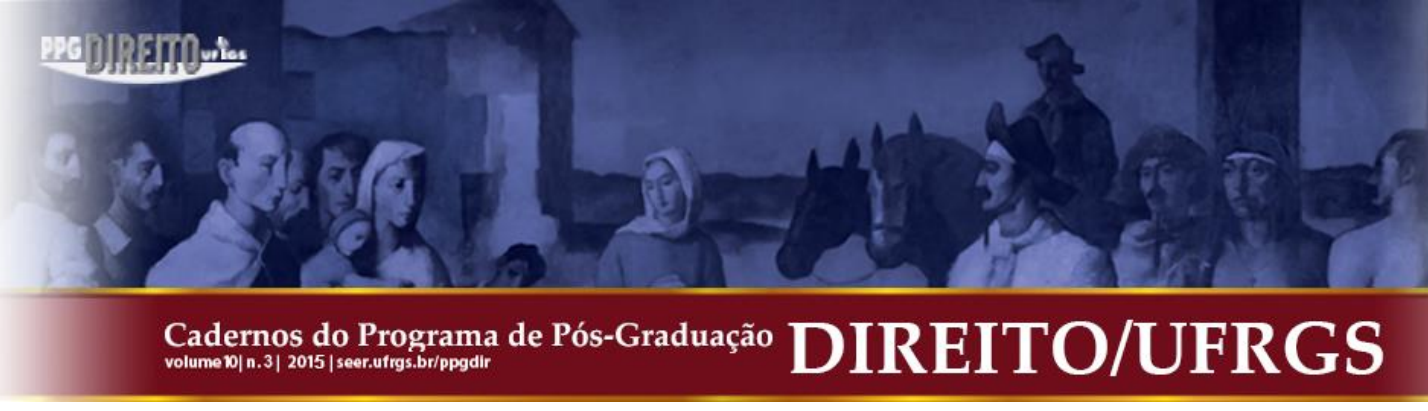

veículo legislativo. ${ }^{9}$ Nesse contexto, seria exigível veículo de maior hierarquia, ou, por outra corrente doutrinária, veículo com potencialidades legislativas distintas, mesmo porque a regulação das imunidades deve ser nacionalmente uniforme, por meio da lei apta a pormenorizar o conteúdo das limitações ao poder de tributar. A lei complementar, pelo quórum qualificado que exige, se eleva sobre a competência de legislar em matéria tributária comum aos entes federados, nos termos do artigo 24, I da Constituição em vigor.

\section{CONCLUSÃO}

De todo o exposto, verificou-se que o Estado Social contemporâneo, calcado nos ideais da solidariedade, mantém-se apenas por meio da estrutura que lhe é disponibilizada pelo Estado Fiscal, fundado em uma concepção de justiça que, no âmbito tributário, se desdobra nos conceitos de segurança jurídica, isonomia e capacidade contributiva.

Se a interpretação do título constitucional atinente à Tributação e ao Orçamento deve se iniciar no preâmbulo de nossa Carta Política, como vem sendo destacado pela doutrina ao discorrer sobre tributos e direitos fundamentais, e se a sua concreção pelos tribunais passa necessariamente pelos "ideais de solidariedade e fraternidade, inspirados no respeito à dignidade de cada um dos nossos semelhantes", como acentuou Luiz Felipe Silveira Difini (2004, p. 184), então o fenômeno tributário considerado em sua inteireza - desde o momento da subsunção do fato econômico à norma jurídica até a sentença extintiva da execução fiscal deve se pautar pela observância de tais valores (Tribunal Regional Federal da 4ª Região, 2014).

Por outro lado, a tributação que enseja a cobrança das cinco espécies tributárias - este dever fundamental dirigido às pessoas dotadas de capacidade contributiva em prol da coletividade - é hoje considerado um fenômeno intersistêmico que envolve a Política, a Economia e o Direito. Os três subsistemas ocupam-se com a equação recursos escassos contrapostos a necessidades de seguridade ilimitadas, o que no âmbito do custeio da seguridade

\footnotetext{
${ }^{9} \mathrm{O}$ art. 146, III, "a” dispõe que fatos geradores, bases de cálculo e contribuintes da espécie tributária imposto devem ser veiculados por lei complementar, estabelecendo um silêncio eloquente acerca das contribuições sociais. Tanto é assim que a LC 70/91, que instituiu a COFINS, é entendida como formalmente lei complementar mas materialmente lei ordinária. Também quando da alegação de inconstitucionalidade da instituição da CSLLContribuição Social sobre Lucro Líquido pela lei 7.689/88 o STF foi enfático ao estabelecer que por não ser a CSLL um imposto "não há necessidade de que a Lei Complementar defina o seu fato gerador, base de cálculo e contribuintes" (STF, pleno, ADI 2010 MC, relator Min Celso de Mello)
} 


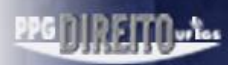 \\ Cadernos do Programa de Pós-Graduação
volume $10 \mid$ n.3| 2015 |seer.ufrgs.br/ppgdir}

social impõe a observância da chamada reserva do possível, assim entendida como limite ao poder do estado de concretizar direitos fundamentais a prestações.

Para expandir os limites da reserva do possível, deve-se agir sobre a despesa pública, implementando efetivamente o princípio da otimização da ação estatal, e sobre a receita, buscando ampliar as bases de financiamento da seguridade sem estrangular as forças produtivas. Uma alternativa à ampliação destas bases é justamente estimular os particulares a oferecer às parcelas menos aquinhoadas da população benefícios e serviços assistenciais, educacionais e de saúde. Esta prestação direta de benefícios e serviços por entidades privadas, atuação que estariam a princípio a cargo do Estado Social de Direito, constitui-se na justificativa filosófica para a imunidade prevista no artigo $195, \S 7^{\circ}$.

Neste contexto, o termo assistência social utilizado na regra imunitória passa a abarcar um amplo espectro, abrangendo não só os serviços de educação, mas até mesmo as entidades de previdência privada que não exijam contraprestação de seus beneficiários. A tutela da segurança jurídica de todos estes atores sociais é melhor efetivada mediante a exigência de lei complementar para veicular a integralidade dos requisitos que condicionam o exercício da imunidade, tanto os de ordem material como os de ordem formal.

Tão só o artigo 14 do CTN, com a sua redação quase cinquentenária, não normatiza de forma suficiente os aspectos mais polêmicos atinentes ao gozo da desoneração constitucional. É um diploma complementar específico que deverá estabelecer a relação entre benefícios subsidiados e benefícios onerosos.

Urge que se edite rapidamente tal norma, pois não se pode deixar à própria entidade assistencial a definição do nível de gratuidade que deseje ofertar. Não é salutar do ponto de vista do interesse coletivo conceder-se tamanha discricionariedade ao ente que pleiteia o benefício imunitório, sob pena de permitir-se a transferência de renda dos setores mais pobres - prejudicados com a renúncia fiscal - aos mais aquinhoados e influentes politicamente, que experimentariam assim a redução de seus custos finais com saúde e educação de qualidade em troca de um número desprezível de bolsas de estudo ou de leitos destinados ao SUS. A renúncia de receita provocada pelo benefício imunitório deve ensejar ganhos proporcionais à população de menor renda, mais necessitada de políticas públicas de saúde e educação e duramente penalizada pela insuficiência e má qualidade destes serviços essenciais, quando prestados diretamente pelas três esferas de governo.

Cadernos do Programa de Pós-Graduação em Direito PPGDir./UFRgS | Edição Digital | Porto Alegre | Volume X | Número 3 | 2015 | P. 166 -190 
- Supremo Tribunal Federal, pleno, Medida Cautelar na Ação Direta de Inconstitucionalidade no 2.028/DF, relator Ministro Moreira Alves, DJ 16/6/2000.

. Supremo Tribunal Federal, pleno, RE 566622, relator Ministro Marco Aurélio, em julgamento (ata de julgamento publicada em 13/06/2014, quatro votos proferidos e autos remetidos ao gabinete do Ministro Teori Zavascki: site do STF www.stf.jus.br, acesso em 23/06/2014).

Supremo Tribunal Federal, pleno, RE 636941, relator Ministro Luiz Fux, sessão de 13/02/2014, acórdão publicado no DJE 04/04/2014.

: Tribunal Regional Federal da $4^{\text {a }}$ Região. Apelação/Reexame Necessário No 5052893 51.2012.404.7100/RS TRF4, relator Jorge Antonio Maurique.

CALIENDO, Paulo. Direito Tributário e Análise Econômica do Direito. São Paulo: Editora Campus/Elsevier, 2008.

CARRAZZA, Roque Antonio. Curso de Direito Constitucional Tributário. 10ª ed. São Paulo: Malheiros Editores Ltda, 1997.

CARVALHO, Paulo de Barros. Curso de Direito Tributário. 6ª ed. São Paulo: Saraiva, 1993.

COSTA, Regina Helena. Curso de Direito Tributário. $3^{\mathrm{a}}$ ed. São Paulo: Saraiva, 2013.

DIFINI, Luiz Felipe Silveira. Manual de Direito Tributário. $3^{\text {a }}$ ed. São Paulo: Saraiva, 2006.

Proibição de Tributos com Efeito de Confisco. Porto Alegre: Livraria do Advogado Ed., 2006.

GRECO, Marco Aurélio. Contribuições (uma figura sui generis). São Paulo: Dialética, 2000.

MACHADO, Hugo de Britto. Curso de Direito Tributário. 22a edição. São Paulo: Malheiros, 2003.

MONTORO, André Franco. Introdução à ciência do direito. 26ª ed. São Paulo: Revista dos 


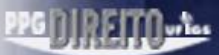

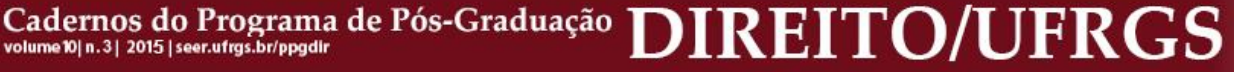

Submissão: 29/09/2015

Aceito para Publicação: 18/12/2015 
